\title{
Influence of Climate Change on Cocoon Crop Loss under Subtropical Conditions
}

\author{
Aradhana Sharma ${ }^{1}$, Suraksha Chanotra ${ }^{1}$, Rucku Gupta $^{2}$ and Rakesh Kumar ${ }^{2}$
}

${ }^{1}$ State Sericulture Development Department, Jammu, Jammu \& Kashmir (India)-180001, P.G. Department of Sericulture, Poonch Campus, University of Jammu, Jammu \& Kashmir (India)-185101

${ }^{2}$ Division of Fruit Science and Plant Pathology-SKUAST-Jammu, India

*Corresponding author

\section{A B S T R A C T}

Keywords

climate, cocoon yield, correlation, diseases, silkworm

Article Info

Accepted:

05 April 2020

Available Online:

10 May 2020
The present study was conducted in three potential cocoon producing districts of Jammu province of J\&K state during 2016-17. The impact of different climatic conditions viz., spring (March-April) and autumn (September-October) on the incidence of major diseases in silkworm were studied. The results indicated the disease incidence was higher during the autumn rearing as compared to spring rearing. Highly significant correlation of temperature and humidity with different diseases and cocoon yield on the basis of ' $r$ ' value was recorded from the studied locations.

\section{Introduction}

The Mulberry silkworm (Bombyx mori L.) is a poikilothermic insect and highly sensitive to environmental conditions. Quality of mulberry leaf and optimum environmental conditions are considered as one of the most important parameter for deciding the success or failure of silkworm rearing. Temperature and humidity poses a direct effect on the larval growth, development and physiological activity, nutrient absorption, digestion, blood circulation and respiration etc. (Neelaboina et al., 2018).

Larval growth and development accelerates at high temperature reduces larval duration, cocoon weight and quality while low temperature slows down growth and development leads to prolonged larval period, abnormal growth, sensitivity against diseases and thus ultimately affects the cost of rearing. For healthy growth and high production of quality cocoons, the optimum temperature 
ranges from $22^{\circ} \mathrm{C}$ to $28^{\circ} \mathrm{C}$ in different instars. Low temperature during late age is considered favourable as it ensures better conversion of leaf protein into silk protein, as food stays longer in the stomach and the digestion and absorption of nutrients is comparatively better (Upadhyay and Mishra, 1994).

In Bombyx mori L., the water content ranges from $77-79 \%$ by weight in larva and $64-69 \%$ in adults (Mathur and Lal, 1994). Humidity influences physiology of silkworm rearing through withering of leaves and sanitation of rearing beds resulting in retarded growth of larvae which makes them weak and easily susceptible to diseases and other adverse conditions. High relative humidity during young age and low during late age results in less crop loss. The optimum relative humidity required for healthy growth of larvae ranges from 65-85 per cent.

The economically important monophagous insect, Bombyx mori L. feed on mulberry leaves and thus quality of mulberry leaf should be appropriate for attaining quality and quantity outputs. Due to changes in climate and agro-ecosystem, there is also a change in the insect pest scenario in mulberry. The phenotypic expression of mulberry is greatly influenced by environmental factors such as temperature, relative humidity, light and nutrition (Thiagarajan et al., 1993).

As mulberry (M. alba) belongs to $\mathrm{C}_{3}$ plant category and is inefficient in utilizing the excess atmospheric carbon dioxide present in the air due to global warming. To overcome this inefficiency, stomata of mulberry leaves remain open for longer periods resulting to increased evapo-transpiration (Ram et al., 2016). Silkworm is one of the most important domesticated insects which produce silk in the form of cocoon by consuming mulberry leaves during its larval period. The growth and development is greatly influenced by the environmental conditions, quality and quantity of leaf. The biological and cocoon related characters get influenced by temperature, humidity, rearing season and quality of mulberry. Different seasons affect the performance of silkworm output and seasonal environmental difference considerably influence the expression of any hybrid in cocoon productivity due to disease incidence. The day and night variations in environmental conditions are not conducive for bivoltine rearing. Unlike multivoltine, bivoltine are more vulnerable to various stresses like poor leaf quality and improper silkworm rearing management particularly in autumn season results into crop losses due to diseases.

The studies on the impact of two most important factors i.e. temperature and humidity contributing in successful cocoon crop under subtropical conditions is not studied ample. Therefore, present study was initiated to analyse its correlation with silkworm disease incidence and crop yield in different seasons.

\section{Materials and Methods}

The present study was undertaken in three major cocoon crop producing districts of Jammu division viz. Kathua, Udhampur and Rajouri having maximum number of silkworm rearers. The sample of the study was initially based on Multistage Sampling Technique. The respondents were selected using Simple Random Sampling without Replacement (SRSWOR) technique using statistical software (MS-excel). Data from random sample of 225 respondents was computed for analysis. The study areas falls under sub-tropical zone situated at an altitude of 300-1350 m MSL. Average annual rainfall of the area is about $1069 \mathrm{~mm}$. The maximum temperature is $32.1{ }^{\circ} \mathrm{C}$ and minimum is $13.6^{\circ} \mathrm{C}$. Thermal index is mild and hydric 
index is humid. Jammu and Kashmir being traditional bivoltine state has two crops per year in spring (Feb-March) and autumn (Sept.-Oct.). The study was conducted in the year 2016-17 and data was collected regarding disease incidence, cocoon crop yield, temperature and humidity. Electronic temperature and humidity meter was used for recording temperature and humidity in the respondents rearing houses. Diseased larvae depicting different microbial symptoms were collected and correlation analysis was used to measure the degree of association between variables such as temperature, humidity, different silkworm diseases incidence and cocoon yield.

\section{Results and Discussion}

Due to global warming and abnormal rainfall patterns, there is continues failure of crop or low crop yield in autumn season inspite of all efforts and utilization of resources. Mulberry silkworm is subjected to viral, bacterial, fungal and protozoan diseases and results in uneconomic crops due to heavy crop losses in autumn season.

The studies on prevalence of different silkworm diseases in subtropical zone of Jammu division of $\mathrm{J} \& \mathrm{~K}$ in commercial seasons were analysed. Occurrence of various diseases in silkworm has direct relationship with various rearing conditions prevailing in rearers rearing/dwelling houses especially irregularities in maintenance of micro climatic conditions and hygiene which leads to outbreak of grasserie and flacherie diseases. In the present study, grasserie disease prevalence was significantly high in all the three districts particularly in autumn season. District Rajouri recorded 37.00 per cent followed by district Kathua (30.85\%). Present study confirms the high prevalence of nuclear polyhedrosis in Jammu division as reported by Illahi and Nataraju (2007), Ali et al.,
(2008), Singh et al., (2009) and Balavenkatasubbaiah et al., (2014).

Fluctuation in temperature during the rearing period disturbs the physiological conditions of silkworm and it makes them susceptible to flacherie disease. Poor quality leaf drastically influences the growth of larvae which makes them prone to bacterial flacherie. In the present study, significant data on incidence of flacherie disease was recorded. Average flacherie disease in seed was maximum in district Rajouri (11.32 \%). Season wise incidence of flacherie disease was more (9.51 $\%$ ) in autumn in comparison to spring. Majority of the rearers did not practice silkworm body and rearing seat disinfection and silkworms were reared in overcrowded conditions. The observations fall in line with Selvakumar et al., (2002).

During field rearing study period, no significant incidence of muscardine disease among the three districts was observed. Negligible incidence was recorded both in spring $(2.93 \%)$ and autumn $(5.17 \%)$ rearing seasons only in Udhampur district. The higher percentage during autumn season approaching winter with low temperature and high humidity overnights could be the predisposing factor for this disease found only in Ghordi circle of Udhampur district. This phenomenon is oftenly observed in muscardine infection because the conidia are light and get easily disseminated by wind and body contact.

The other factors responsible for fungal disease (muscardine) incidence requires further detailed studies of the particular area which was observed at a negligible incidence. The spread of white muscardine is reported to be disastrous than other diseases by Parmesan et al., (2003) and Rahmatulla et al., (2012). No any incidence of pebrine has been observed during study period in the field. Strict monitoring of this transovarial disease 
at seed maintenance and multiplication system and supply of disease free layings/larvae to the silkworm rearers resulted no incidence of this deadly disease. The correlation co-efficient ' $r$ ' values between most important predisposing factors i.e., temperature and humidity and silkworm diseases such as grasserie, flacherie, muscardine incidence and cocoon yield in autumn season is presented in the Table 1 .

A positive correlation was observed between temperature and diseases viz. grasserie (0.74) and flacherie (0.80). The correlation coefficient data indicated that when temperature rises up in last instar, the disease incidence was high whereas negative correlation with the muscardine disease incidence (-0.46) indicates low fungal infection due to high temperature. Similarly, a significant negative correlation between temperature and cocoon yield (-0.72) indicated low yield when temperature rises.

Correlation studies were also estimated between humidity and different diseases. Highly significant and positive correlation was observed between humidity and different disease. The coefficient correlation ' $r$ ' values (0.47, 0.37 and 0.56) indicated that with the rise of humidity, there is high disease incidence due to viral, bacterial and fungal microbes. However, negative and highly significant relationship was found with cocoon yield $(-0.52)$ confirms the reason for low cocoon crop due to rise in humidity.

Table.1 Correlation coefficient (r) value between temperature, humidity, different silkworm diseases and cocoon yield

\begin{tabular}{|l|l|c|c|c|c|}
\hline S.no. & Environmental factors & \multicolumn{3}{|c|}{ Disease incidence } & Cocoon \\
\cline { 3 - 6 } & & Grasserie & Flacherie & Muscardine & yield \\
\hline 1. & Temperature & $0.74 * *$ & $0.80 * *$ & $-0.46 * *$ & $-0.72 * *$ \\
\hline 2. & Humidity & $0.47 * *$ & $0.37 * *$ & $0.56 * *$ & $-0.52 * *$ \\
\hline$* *$ refers & significance level at 1\% & & &
\end{tabular}

The correlation coefficient values concluded that the high viral and bacterial infection was recorded in autumn season due to high temperature and humidity. Weather is one of the important factors that influences disease incidence in silkworm. So adoption of recommended practices for effective crop protection during harsh conditions of autumn season can help the respondents to overcome the crop loss.

\section{Acknowledgements}

The authors are highly thankful to State Sericulture Development Department, Jammu for their cooperation and precious support during this field study.

\section{References}

Ali, A. and Rizvi, P.Q. 2008. Effect of varying temperature on the survival and fecundity of Coccinellaseptem punctata (Coleoptera:Coccinellidae) fed on Lipaphiserysimi (Hemiptera: Aphididae). Journal of Entomology. 5:133-137.

Balavenkatasubbaiah, M., Shivashankar, N., Maheswari, M., Mathur, V.B., Chandrasekharan, K. and Narasimha, N.A.R. 2014. Prevalence of silkworm diseases and their impact on cocoon productivity in the selected areas of Karnataka, India. Indian Journal of Sericulture. 53(2):51-59. 
Illahi I, Nataraju B. 2007. Prevalence of nuclear polyhedrosis in mulberry silkworm, Bombyx mori L. in Jammu and Kashmir. Indian Journal of Sericulture.46(1):43-48.

Mathur, S. K., Lal, S. B. 1994. Effects of temperature and humidity on the adaptability of insects.Indian Textile Journal. 136: 34-47.

Neelaboina, B. K., Khan, G. A., Kumar, S., Gani, M., Ahmad, M. N. and Ghosh, M. K. 2018. Impact of climate change on agriculture and sericulture.Journal of Entomology and Zoology studies. 6(5): 426-429.

Parmesan, C.R. and Yohe, G. 2003. A globally coherent fingerprints of climate change impacts across natural systems. Nature. 421:37-42.

Rahmatulla, V.K., Kumar, C.M.K., Angadi, B.S. and Sivaprasad, V. 2012. Influence of weather factors on incidence and intensity of microsporidiosis in silkworm (Bombyxmori L). Journal of Entomology. 9(5):266-273.

Ram, R. L., Maji, C. and Bindroo, B. B. 2016. Impact of climate change on sustainable sericultural development in
India.International Journal of Agriculture Innovations and Research. 4(6):110-118.

Selvakumar T, Nataraju B, Balavenkatasubbaiah M, Sivaprasad V, Baig M. 2002. A report on the prevalence of silkworm diseases and estimated crop loss. Advances in Indian Sericulture Research, CSRTI, Mysore. 357-357.

Singh, T., Bhat, M. M. and Khan, M. A. 2009. Insect adoptations to changing environments-Temperature and Humidity.International Journal of Industrial Entomology. 19 (1):155-164.

Thiagarajan, V., Bhargava, S. K., Ramesh, B. M. and Nagaraj, B. 1993. Differences in seasonal performance of twenty six strains of silkworm, Bombyx mori (Bombycidae). Journal of the Lepidopterists Society.47:331-337.

Upadhyay, V. B. and Mishra, A. B. 1994. Influence of temperature on the passage of food through gut of multivoltine Bombyxmorilarvae. Indian Journal of Sericulture. 33(2):183-185.

\section{How to cite this article:}

Aradhana Sharma, Suraksha Chanotra, Rucku Gupta and Rakesh Kumar. 2020. Influence of Climate Change on Cocoon Crop Loss under Subtropical Conditions. Int.J.Curr.Microbiol.App.Sci. 9(05): 167-171. doi: https://doi.org/10.20546/ijcmas.2020.905.018 